\title{
PROBLEMS OF CONTINUITY OF INSTITUTIONS OF REGIONAL GOVERNANCE
}

\section{K. Yu. Proskurnova}

Yaroslavl branch of Financial University under the Government of the Russian Federation, Yaroslavl, Russia e-mail: proskurnova@hotmail.com

Abstract. The relevance of the topic addressed in the article is due to fact that stable economic growth of the region is based on human capital, resources and government policies as well as institutions and effectiveness of its functioning. Regional administration changes don't let regional administration institutions to evaluate and develop.

The aim of the study is to identify the impact of regional administration changes on region development.

The article analyzes the regional administration institutions functioning on the example of Yaroslavl region.

We used the research methods of regional administration institutions, the construction of logic circuits, as well as abstract logical, tabular and expert scientific methods.

The article provides a comparative analysis of the «institution» concept definitions given by representatives of different economic schools. The analysis of the regional administration institution is based on the formal and informal institutions operating in the region, the adopted regional development projects and economic indicators. The influence of formal and informal institutions on the development of each other and on the development of the region is the subject of further research.

As part of the study, proposed to regional administration to use experience of previous administration and consider availability and influence of regional informal institutions on development.

The materials of the article can be used in their activities by representatives of public authorities, lecturers, and can also be useful in the process of teaching and research to students and graduate students.

Keywords: institution, formal and informal institutions, regional administration, region development.

Cite as: Proskurnova, K. Yu. (2020) [Problems of continuity of institutions of regional governance]. Intellekt. Innovatsi. Investitsii [Intellect. Innovation. Investments]. Vol. 2, pp. 60-66. DOI: 10.25198/2077-7175-2020-2-60.

\section{ПРОБЛЕМЫ ПРЕЕМСТВЕЕННОСТИ ИНСТИТУТОВ РЕГИОНАЛЬНОГО УПРАВЛЕНИЯ}

\section{К. Ю. Проскурнова}

Ярославский филиал Финансового университета при Правительстве Российской Федерации, Ярославль, Россия

e-mail: proskurnova@hotmail.com

Аннотация. Актуальность рассматриваемой в статье темы обусловлена тем, что устойчивый экономический рост региона обеспечивается не только человеческим капиталом, материальными и финансовыми ресурсами и государственной политикой, но и существующими институтами и степенью эффективности их функиионирования. Постоянные изменения в региональных органах власти не позволяют институтам регионального управления эволючионировать и развиваться.

Целью исследования являлось определение влияния изменений, происходящих в региональном управлении, на развитие территорий.

В статье проведен анализ функционирования институтов регионального управления на примере Ярославской области.

В работе были использованы методы исследования институтов регионального управления, конструирования логических схем, а также абстрактно-логические, табличные и экспертные научные методы.

В статье проведен сравнительный анализ трактовок понятия «институт», данных представителями различных экономических школ. Анализ институтов регионального управления осуществлен на основе формальных и неформальных институтов, существующих в регионе, принятых проектах регионального развития и экономических показателей. Влияние формальных и неформальных институтов на развитие друг друга и отдельно на развитие региона является предметом дальнейших исследований. 
В рамках проведенного исследования региональным органам государственного управления предложено использовать опыт и достижения предыдущчи администраций и учитывать наличие и влияние неформальных институтов на развитие регионов.

Материал статьи может быть использован в своей деятельности представителями органов государственной власти, преподавателями, а также могут быть полезны в процессе обучения и научных исследований студентам и аспирантам.

Ключевые слова: институт, формальные и неформальнье институть, региональнье органь власти, развитие региона.

Для цитирования: Proskurnova, K. Yu. (2020) [Problems of continuity of institutions of regional governance]. Intellekt. Innovatsi. Investitsii [Intellect. Innovation. Investments]. Vol. 2, pp. 60-66. DOI: 10.25198/2077-71752020-2-60.

\section{Introduction}

An assessment of the subjects functioning effectiveness is based on economic indicators and an analysis of the use of material resources. In recent decades emphasis has also been placed on the intangible resources that economic entities and territories possess. Such phenomenon as an institution should be considered to minimize negative influences and maximize the desired results. Institutions can be the external environment in which they function, the condition that ensures these functioning processes and the goal of the subject functioning in itself.

Building a management system which takes into account the development features of the management object - the region, specific features of informal institutions of a certain territory, the existing formal norms and rules of various levels - can provide a synergistic effect from the interaction of formal and informal institutions both as a framework and as a tool. Regional informal institutions can negatively affect performance of both the entire region and business entities if their activities are not taken into account.

\section{Comparative Analysis of the «Institution» Concept}

Institutions are an integral part of any area of society. In different variations their presence can be detected both at the micro level (organizations or groups of people), and at the macro level - states or groups of states. Despite of the fact that institutionalism as a science direction has been developing for more than 100 years, a uniform definition of the concept of «institution» has not yet been formulated because there is no single school and no unified research methodology in this scientific direction. An analysis of the definitions of the «institution» concept given by various Russian and foreign authors allows us to divide them into two groups - informal and formal institutions. Such a division is caused not by the formal and informal components, but by the approaches to the interpretation of the term and according to the object of analysis.

In our opinion the first group of «informal institutions» includes the ones that were formulated by the authors relating to the old school of institutionalism, the German historical school and some representatives of new institutional economics.
G. Schmoller gave his definition of institutions as «a certain order of living together, which serves specific purposes and has the potential for independent evolution» $[1,61]$. This option reflects a certain system of people's behavior in interaction with each other; at the same time the evolutionary component has been attributed to institutions, i.e. their ability to change as a result of external and internal factors.

At the same time Th. Veblen devoted the most part of his scientific paper «The Theory of the Leisure Class», to the review of social institutions. He defined institutions as «prevalent habits of thought with respect to particular relations and particular functions of the individual and of the community; and the scheme of life, which is made up of the aggregate of institutions in force at a given time or at a given point in the development of any society, may, on the psychological side, be broadly characterized as a prevalent spiritual attitude or a prevalent theory of life» [2, 118]. Th. Veblen emphasized the «prevalent habits of thought» on the human interaction system.

Another representative of the old school of institutionalism, Walton Hamilton, identified the institution as «a verbal symbol which for want of a better describes a cluster of social usage» and «a way of thought or action of some prevalence and permanence, which is embedded in the habits of a group or the customs of a people» [3, 84]. In this version institutions have been defined as habits that are specific to a particular group of people.

J. R. Commons" definition "collective action in control of individual action», cited by B. Seligman, does not allow us to categorize it unconditionally as a group of informal institutions, but the absence of any formalization of action or mechanism and the emphasis on control, accepts this option as an informal institution based on an agreement between participants about a certain behavior or on an interaction formed during the evolution, and as a formal one, involving the mechanism of group control over the behavior of individuals, which is provided in written form [4, 164].

G. Hodgson, in the same way as Th. Veblen, considered institutions not only within the framework of economic behavior, but also as a social object - «systems of established and prevalent social rules that structure social interactions» $[5,2]$. 
Russian economist V. V. Volchik quotes W. Cl. Mitchell's definition of the institutions as «dominant and highly standardized social habits» [6]. Despite of the fact that W. Cl. Mitchell specialized in a statistical study of economic processes, however, this definition reflects the sociological approach to the analysis of group behavior, including economic one.

S. G. Kirdina's definition of «institutional matrix» cannot be attributed to informal or formal forms of institutions; nevertheless it does not imply a strictly fixed mechanism of interaction - «complex structured and functionally differentiated systems having various elements and components» $[7,82]$.

Neo-Marxist political economist S. Bowles uses institutions for microeconomic analysis and defines them as «laws, informal rules and agreements that provide a long-term basis for social interactions among the members of a population» $[8,48]$.

The second group of definitions is given mainly by representatives of the neo-institutional direction; it contains elements related to formal institutions.

T. Parsons is credited with criticizing both the neoclassical direction in economics and the institutional one, but he didn't deny any neoclassical approach to research, in contrast to the approach of institutionalists. Changing economic profiling to sociological one, T. Parsons defined institutions as «normative patterns which define what are felt to be, in the given society, proper, legitimate, or expected modes of action or of social relationship» $[9,190]$. The obligation factor as a constituent element of the rule implies obligations for people to perform specific actions.

The most cited definition in the scientific literature belongs to Douglas North. According to North institutions are «the rules of the game in a society or, more formally, are the humanly devised constraints that shape human interaction» $[10,3]$. A modified definition concept is used by the Ronald Coase Institute in a website glossary «the rules of the game: the humanly devised constraints that structure human interaction. They are made up of formal constraints (such as rules, laws, constitutions), informal constraints (such as norms of behavior, conventions, self-imposed codes of conduct), and their enforcement characteristics» $[11$, 12]. V. V. Volchik gives a definition of «institutional structure» based on the term «institution» given by other authors - «a certain ordered set of institutions that create matrix of economic behavior that define restrictions for economic entities that are formed within the framework of a particular system of coordination of economic activity» $[13,23]$.

J. D. Schaffer uses more than one definition of the institution in his papers - determining it as «the formal and informal rules which govern or at least influence the behavior of participants of a society as they interact in political and economic activities» [14] and «the rules which regulate economic interactions and rela- tionships: the laws, customs, enforcement procedures which regulate transactions, defining who's preferences count and how they are counted in the processes of production, distribution and consumption» [15].

Neither O. Williamson's papers nor Volchik's ones contain such a concept as «institution» but they gave notions of «institutional environment» - «the rules of the game that define the context within which economic activity take place», - and «institutional set-up» - «the contractual relation or governance structure between economic entities that defines the way in which they co-operate and/or compete» $[16,55]$.

Elinor Ostrom defined institutions as «the sets of working rules that are used to determine who is eligible to make decisions in some arena, what actions are allowed or constrained, what aggregation rules will be used, what procedures must be followed. What information must or must not be provided, and what payoffs will be assigned to individuals dependent on their actions» $[17,51]$. This definition contains elements of formal institutions, «legislatively» securing the roles, functions, and mechanisms of interaction between participants.

In the works of Russian economists interpretation of formal institutions has become more widespread. Thus, V. L. Tambovtsev assumes that institutions are «the rules or the sets of rules that have an external enforcement mechanism for individuals» $[18,32]$, and D. P. Frolov interprets them as «the institutional and operational modalities of economic activity, the associated norms, rules and procedures that form the regulatory mechanisms of transactions between their agents» $[19,5]$.

Fixing in writing or orally the norms of behavior is reflected in the interpretation of the term given by N. D. Drozdov «the set of formal (fixed in the law), informal (fixed in customary law - contracts, voluntarily adopted laws of behavior) and spontaneous frameworks that structure human interaction in the economic, political and social spheres» $[20,7]$.

Like G. Schmoller, G. B. Kleiner defined institution as «relatively stable in relation to changes in the behavior or the interests of individuals and their groups, as well as formal and informal norms or the sets of norms that continue to operate for a significant period of time, regulating decision-making, activities and interaction of socio-economic entities (individuals and legal entities, organizations) and their groups» $[21,8]$. The presence of a regulatory function allows us to attribute the Kleiner's definition to a large extent to formal institutions.

Trying to combine all approaches to the definition of this term we identify intuition as a combination of formal and informal norms and rules, familiar and routine ways of action, customs and traditions that describe and regulate the behavior of individuals and groups in a certain area of life $[22,55]$. 
The Functioning of Regional Administration

Institutions in the Former Industrial Regions

Despite of all different approaches both to the definition of institutions and the classification of institutions based on their main constituent elements, the convergence and divergence of institutions, primarily formal and informal, significantly affect the functioning and development of socio-economic systems. The problems of the interaction between formal and informal institutions and their impact on the economic performance will be analyzed on the example of the Yaroslavl region.

The Yaroslavl region has an advantageous geographic position not only in relation to the capital, but also to other regions of the country. Historically, Viking trade routes ran along the Volga River so the way station from the Sheksna River to the Volga River was located near modern Yaroslavl. Later, it was the direction of trade flows, including from and to the capital that allowed the city to develop merchant class. The development of entrepreneurial culture laid the foundations for the emergence of industry, which was built mainly by merchants in this particular region. Many of those enterprises have still been operating, for example, the Yaroslavl Bolshaya Manufaktura (now AO (JSC) Krasny Perekop) founded in 1722, a lead-bleaching plant (AO (JSC) Russkie Kraski) set up in 1838, the leather factory of the merchant Ikonnikov and a number of other leather plants (now, AO (JSC) Chrom) founded in 1862, the Yaroslavl tobacco factory (in 2017 the factory was closed) set up in 1850 . The developing entrepreneurial culture allowed many peasants who received freedom to create successful enterprises outside the region, among them were P. E. Eliseev (trading enterprises), P. A. Smirnov (vodka production), N. P. Pastukhov (metallurgical enterprises, flour mills, shops of the Nizhny Novgorod Fair), etc. Availability of production facilities, the Volga River as the main transport and energy artery led to the development of engineering and chemical industries in the region during the Soviet period.

The development of merchant class (trade) and industry over several centuries has been formed by such informal institutions as entrepreneurial and industrial cultures. Despite of the economic degradation in the 1990s, which negatively affected the regional industry, production was maintained.

If we consider the dynamics of the volume index of gross regional product in 1998-2017 (Table 1), the Yaroslavl region GRP declines occurred at the crisis years (1998 and 2009), GRP grew up in the other years. Nevertheless, there were lower growth rates compared to the average national ones - in 2000, 2002-2003, 2005, 2007-2008, 2010.

Table 1. The volume of gross regional product in 1998-2017, at constant prices, in $\%$ to the previous year

\begin{tabular}{|l|c|c|c|c|c|c|c|c|c|c|}
\hline & \multicolumn{7}{|c|}{ Year } \\
\cline { 2 - 11 } & $\mathbf{1 9 9 8}$ & $\mathbf{1 9 9 9}$ & $\mathbf{2 0 0 0}$ & $\mathbf{2 0 0 1}$ & $\mathbf{2 0 0 2}$ & $\mathbf{2 0 0 3}$ & $\mathbf{2 0 0 4}$ & $\mathbf{2 0 0 5}$ & $\mathbf{2 0 0 6}$ & $\mathbf{2 0 0 7}$ \\
\hline $\begin{array}{l}\text { GRP by constituent entities of } \\
\text { the Russian Federation (GVA } \\
\text { at basic prices), total }\end{array}$ & 93,5 & 105,6 & 110,6 & 106,0 & 105,5 & 107,6 & 107,4 & 107,6 & 108,3 & 108,3 \\
\hline Yaroslavl region & 90,1 & 111,5 & 107,7 & 109,7 & 103,5 & 104,4 & 108,3 & 105,9 & 110,5 & 106,5 \\
\hline & $\mathbf{2 0 0 8}$ & $\mathbf{2 0 0 9}$ & $\mathbf{2 0 1 0}$ & $\mathbf{2 0 1 1}$ & $\mathbf{2 0 1 2}$ & $\mathbf{2 0 1 3}$ & $\mathbf{2 0 1 4}$ & $\mathbf{2 0 1 5}$ & $\mathbf{2 0 1 6}$ & $\mathbf{2 0 1 7}$ \\
\hline $\begin{array}{l}\text { GRP by constituent entities of } \\
\text { the Russian Federation (GVA } \\
\text { at basic prices), total }\end{array}$ & 105,7 & 92,4 & 104,6 & 105,4 & 103,1 & 101,8 & 101,3 & 99,4 & 100,8 & 101,8 \\
\hline Yaroslavl region & 101,1 & 91,9 & 103,0 & 107,0 & 104,6 & 102,6 & 101,9 & 100,4 & 101,2 & 102,3 \\
\hline
\end{tabular}

Among the important institutions of development in any region is the institution of public administration. There have been 4 governors in the modern history of the Yaroslavl region, three of them held the post in succession from 2007 to the present time. The national rating of governors has been published since 2014 and shows unfavorable changes in the assessment of the Yaroslavl governor's performance, namely, a gradual decrease of their positions in a rating $-\mathrm{S}$. N. Yastrebov lost 10 ranking positions after governing the region for a year, and D. Yu. Mironov fell by 9 positions after governing the region for 3 years, there was a significant decrease of 14 points in 2018 compared to 2017 (Table 2). The highest rating was awarded to the first governor of the Yaroslavl region A. I. Lisitsyn, who took the $6^{\text {th }}$ and the $4^{\text {th }}$ places in 2003 and 2004 accordingly in the rating of lobbyists - regional leaders, conducted by experts of Nezavisimaya Gazeta and Economic News Agency.

Table 2. Rating of the Yaroslavl region governors in the National ranking of governors

\begin{tabular}{|l|c|c|c|c|c|c|}
\hline \multicolumn{2}{|c|}{ Governor } & \multicolumn{6}{c|}{ Year } & 2019 \\
\cline { 2 - 8 } & 2014 & 2015 & 2016 & 2017 & 2018 & \\
\hline S. N. Yastrebov & 48 & 58 & & & & 32 \\
\hline D. Yu. Mironov & & & 26 & 28 & 42 & 35 \\
\hline
\end{tabular}

According to http://russia-rating.ru/info/category/gubernators 
The fact, that 3 governors have been replaced in the Yaroslavl region over the past 12 years did not have a positive effect on the building of formal institutions for the regional development, especially taking into account the fact that, the present Yaroslavl governor team is mainly formed not from local experts, but from the other regions. The negative trend in the institutions of development can be traced on the example of the strategic programs creation and adoption. The current Strategy of Socio-Economic Development of the Yaroslavl region until 2025, which was signed in 2014, was changed and filled up in 2017-2019, is the main document and underlies the programs implemented in the region, operates within federal legislation on strategic planning and refers to the «standard» documents.

At the same time, a draft Strategy for Spatial Development of the Yaroslavl Region was worked out in the region. It included a territorial planning scheme, the region's infrastructure development, supposed to provide conditions for the socio-economic development for all municipalities in the region. This document can be called unique, because until 2019 when the Strategy for Spatial Development of the Russian Federation was signed, not any region of the Russian Federation created or signed project like that, except of Yekaterinburg, where the draft Strategy for Spatial Development of the City was included in the Strategic Development Plan of Yekaterinburg.

A feature of the Spatial Development Strategy of the Yaroslavl Region was it included not only territorial planning, but projects to develop social, transport, industrial and another infrastructure to provide the sta- ble development of every economic sector of the region, small and medium-sized businesses, as well as the creation of innovative enterprises.

Competition inside the regional administration institutions and the lack of continuity led to the rejection of strategically important documents for the region development. It was confirmed by a verbal survey of civil servants from some departments of the Yaroslavl Region Government.

Non-inclusion of the Yaroslavl region in various pilot projects implemented on the territory of the country also affects the reduction of lobbying positions for the interests of the region. Testing of the special tax regime for the self-employed population «Profit tax» began in Moscow, the Moscow and Kaluga regions, and the Republic of Tatarstan in 2019. The project has been extended to 19 more regions in 2020, but the Yaroslavl region is not on this list. Despite of the fact that the region has a self-employed population, not only in the service sector (for example, tutoring), but in the manufacturing sector (the tourism industry in the region contributes to the development of souvenir production by the selfemployed population).

It can be noted that it is difficult to conduct a comparative analysis regarding efficiency of regional administration institutions due to the fact that each part of the Russian Federation has completely different characteristics - socio-economic, infrastructural, climatic, geographical and historical aspects of development. Nevertheless, taking into account such factors as the climatic and geographical conditions, belonging to former industrial regions, one can compare Kaluga and Yaroslavl regions.

Table 3. Indicators of the Kaluga and Yaroslavl regions

\begin{tabular}{|l|c|c|c|c|}
\hline \multicolumn{1}{|c|}{ Region } & $\begin{array}{c}\text { Population at 01/01/2018, } \\
\text { thousand people }\end{array}$ & Area, km2 & $\begin{array}{c}\text { GRP in 2017, } \\
\text { million rubles }\end{array}$ & $\begin{array}{c}\text { GRP per capita in 2017, } \\
\text { rubles }\end{array}$ \\
\hline Kaluga region & 1012 & 29777 & 417065,0 & 411565,3 \\
\hline Yaroslavl region & 1266 & 36400 & 510631,5 & 402639,5 \\
\hline
\end{tabular}

Both regions belong to the depressed former industrial regions, border to the Moscow region and have territories similar in area. The population of the Yaroslavl region is $25 \%$ more than the Kaluga region. But, despite of the GRP excess in 2017 in the Yaroslavl region, the GRP per capita in the Yaroslavl region was 2\% less than in the Kaluga region. So, one can make a conclusion about the greater efficiency of the Kaluga region economy (Table 3 ).

Table 4. Indicators of industrial and manufacturing production of the Kaluga and Yaroslavl regions

\begin{tabular}{|l|c|c|c|c|c|c|}
\hline \multirow{2}{*}{} & \multicolumn{3}{|c|}{ The volume of industrial production, million rubles } & \multicolumn{3}{|c|}{ The volume of manufacturing, million rubles } \\
\cline { 2 - 7 } & 2015 & 2016 & 2017 & 2015 & 2016 & 2017 \\
\hline Kaluga region & 464314 & 561482 & 714487 & 441634 & 537625 & 683965 \\
\hline Yaroslavl region & 322549 & 348237 & 392304 & 289256 & 312464 & 338290 \\
\hline
\end{tabular}

According to gisip.ru 
An analysis of industrial production indicators suggests that industrial policy is better implemented in the Kaluga region than in the Yaroslavl region, with the manufacturing sector in the former region accounting for more than $95 \%$, and the latter - less than $90 \%$. The
Kaluga region has such indicators due to the active position of the regional administration in attracting manufacturers and implementing projects to create industrial and technology parks (see Table 5).

Table 5. Share of industrial parks in the manufacturing industry of the Kaluga and Yaroslavl regions

\begin{tabular}{|l|c|c|c|}
\hline \multirow{2}{*}{} & \multicolumn{3}{|c|}{ The dynamics of the industrial park contribution, \% } \\
\cline { 2 - 4 } & 2015 & 2016 & 2017 \\
\hline Kaluga region & $58,17(10)$ & $47,65(9)$ & $37,46(9)$ \\
\hline Yaroslavl region & $0,59(2)$ & $0,54(2)$ & $0,50(2)$ \\
\hline
\end{tabular}

In parentheses the number of parks for which the calculation has been done is indicated

According to gisip.ru

Geo information system «Industrial parks. Technoparks. Clusters" site (https://www.gisip.ru/) provides data (in 2019) on 2 operating, 1 emerging universal industrial parks in the Yaroslavl region and on 9 operating, 1 developing universal industrial parks and 2 clusters in Kaluga region. Information about the pharmaceutical cluster of the Yaroslavl region is not available in this geo information system.

It can be concluded that the efficiency of regional administration institutions differs in various regions. This fact is reflected in their leaders' positions among the heads of the constituent regions of the Russian Federation (the Kaluga region governor is in the first group in the 2019 ranking of governors - in the 21st place).

The Yaroslavl region is in a state of stagnation despite of the fact that the region has a fairly large-scale material and production base, scientific and technical potential, as well as historically formed informal institutions (like entrepreneurial and industrial culture).

Thus, to ensure the economic development of territories, regional leaders need to interact not only with formal federal and regional institutions, but also implement innovative and unique projects (institutions) of their predecessors (for example, the draft Strategy for Spatial Development of the Yaroslavl Region), and also take into account the existing in each region informal institutions with specific features that are capable of increasing the efficiency of the programs and activities which are being implemented.

\section{Conclusion}

Performance of the regional administration institutions based on uniform norms and rules (federal legislation) produces different results in terms of the development of territories. In addition to the formal norms and rules that underlie decision-making by regional leaders, it is necessary to take into account those informal institutions that have spread throughout the territory of each region of the Russian Federation, since divergence processes of formal and informal regional institutions can negatively affect not only the implementation of existing development programs, but also ones that are being formed.

\section{References}

1. Schmoller, G. von. (1900) Grundriss der Allgemeinen Volkswir. tschaftslehre. Munich and Leipzig: Dunkker and Humblot. (In Germ.).

2. Veblen, Th. (2012) The Theory of the Leisure Class. Dover Thrift Editions. New York: Courier Corporation, 256 pp. (In Eng.).

3. Hamilton, W. (1932). Institution: Encyclopedia of the Social Sciences. New York, Vol. VIII, pp. 84-89. (In Eng.).

4. Seligman, Ben B. (1962) Main Currents of Modern Economics Thoughts. New York: Free Press of Glencoe, 887 pp. (In Eng.)

5. Hodgson, G. M. (2006). What Are Institutions? Journal of Economic Issues, 40(1), pp. 1-25. (In Eng.).

6. Volchik, V. V. (2002) Lekstii po Institutsional'noy Ekonomike [Lectures on Institutional Economics]. Rostov-on-Don.

7. Kirdina, S. G. (2005) [Theory of Institutional Matrix]. Postsovetskiy Institutsionalism [Post-Soviet Institutionalism]. Donetsk: Kashtan, 480 pp. (In Russ.).

8. Bowles, S. (2004) Microeconomics: Behavior, Institutions, and Evolution. Princeton University Press, $608 \mathrm{pp}$.

9. Parsons, T. (1940) The Motivation of Economic Activities. Canadian Journal of Economics and Political Science, No. 6, pp. 187-203. (In Eng.). 
10. North, D. C. (1990). Institutions, Institutional Change and Economic Performance. Cambridge: Cambridge University Press, $152 \mathrm{pp}$.

11. North, D. C. (1994) Economic Performance Through Time, Nobel prize lecture, December 19, 1993. The American Economic Review, 84 (3), pp. 359-368. (In Eng.).

12. The Ronald Coase Institute (2020) Glossary for New Institutional Economics. Available at:https://www. coase.org/nieglossary.htm\#Institutions (accessed 17.01.2020) (In Eng.).

13. Volchik, V. V. (2011) Institutsional'naya i Evolutsionnaya Ekonomika [Institutional and evolutional economy]. Rostov-on-Don: YuFU Publishing, 228 pp. (In Russ.).

14. Shaffer, J. D. (1995) Institutions, Behavior and Economic Performance; Comments on Institutional Analysis. Available at: https://msu.edu/user/schmid/shaffer.htm (accessed 17.01.2020) (In Eng.).

15. Shaffer, J. D. (1997) Institutions, Organizations and Food Systems Performance: Observations From Over The Hill. Available at: https://msu.edu/user/schmid/shaffer2.htm (accessed 17.01.2020) (In Eng.).

16. Williamson, O. E. (1993) The Economic Analysis of Institutions and Organisations. In General And With Respect to Country Studies. Paris: Organisation for Co-operation and development, 75 pp.

17. Ostrom, E. (1990) Governing the Commons: The Evolution of Institutions for Collective Action. Cambridge: Cambridge University Press, $280 \mathrm{pp}$.

18. Auzan, A. A. (2011) Institutsional'naya Ekonomika: Novaya Institutsional'naya Ekonomicheskaya Teoria [Institutional Economics: A New Institutional Economic Theory]. 2n ed Moscow: INFRA-M, 447 pp.

19. Frolov, D. P. (2011) [Institutions and Transactional Costs: Overcoming the Quasicouzian Tradition]. Voprosy regulirovaniya ekonomiki [Journal of Economic Regulation]. Vol. 2, No. 4, pp. 5-23. (In Russ.).

20. Drozdov, N.D. (2006) Institutsional'naya Ekonomika [Institutional Economics]. Tver: Tver State University, 156 pp.(In Russ.).

21. Kleyner, G.B. (2016) [Institutions: definition, signs and direction of research]. Upravlenie [Management]. Vol. 3 (13), pp. 5-11. (In Russ.).

22. Proskurnova, K. Yu. (2019) Institutsional'nye osnovy regional'nogo razvitiya [Institutional basics of regional development].Yaroslavl: PFK “Soyuz-Press” Ltd.,74 pp.

Information about the author:

Ksenia Yurievna Proskurnova, Candidate of Economical Sciences, Associated Professor, Department of Economy and Finance, Yaroslavl branch of Financial University under the Government of the Russian Federation, Yaroslavl, Russia

SPIN-code RSCI: 2742-9482

e-mail: proskurnova@hotmail.com

The paper was submitted: 28.01.2020.

Accepted for publication: 28.02.2020.

The author has read and approved the final manuscript.

Информация об авторе:

Ксения Юрьевна Проскурнова, кандидат экономических наук, доцент кафедры экономики и финансов, Ярославский филиал Финансового университета при Правительстве Российской Федерации, Ярославль, Россия

SPIN-код РИНЦ: 2742-9482

e-mail: proskurnova@hotmail.com

Статья поступила в редакцию 28.01.2020; принята в печать 28.02.2020.

Автор прочитал и одобрил окончательный вариант рукописи. 